\title{
Improvement of Open-Circuit Voltage in Organic Photovoltaic Cells with Chemically Modified Indium-Tin Oxide
}

\author{
Khayankhyarvaa Sarangerel ${ }^{1}$, Byambasuren Delgertsetseg ${ }^{2}$, Namsrai Javkhlantugs ${ }^{2}$, \\ Masaru Sakomura ${ }^{3}$, Chimed Ganzorig ${ }^{2,4}$ \\ ${ }^{1}$ Department of Electronics and Computer, School of Power Engineering, Mongolian University of Science and Technology, \\ Ulaanbaatar, Mongolia \\ ${ }^{2}$ Center for Nanoscience and Nanotechnology, Department of Chemical Technology, School of Chemistry and \\ Chemical Engineering, National University of Mongolia, Ulaanbaatar, Mongolia \\ ${ }^{3}$ Department of Chemistry, Chemical Engineering and Life Science, Yokohama National University, Yokohama, Japan \\ ${ }^{4}$ Faculty of Engineering, New Mongol Institute of Technology, Ulaanbaatar, Mongolia \\ Email: ch_ganzorig@num.edu.mn
}

Received August 12, 2013; revised September 13, 2013; accepted September 20, 2013

Copyright (C) 2013 Khayankhyarvaa Sarangerel et al. This is an open access article distributed under the Creative Commons Attribution License, which permits unrestricted use, distribution, and reproduction in any medium, provided the original work is properly cited.

\begin{abstract}
The possibility of the increase in open-circuit voltage of organic photovoltaic cells based primarily indium-tin oxide (ITO)/rubrene/fullerene/Al structure by changing the work function of ITO anodes and Al cathodes was described in this work. To change built-in potential preferably in order to increase the open-circuit voltage, the work function of ITO should be increased and work function of Al should be decreased. The correlation between the change in work functions of electrodes and performance of the organic photovoltaic cells before and after surface modifications was examined in detail. The enhancement of open-circuit voltage depends on a function of work function change of both ITO and Al electrode. We could show that the built-in potential in the cells played an important role in open-circuit voltage.
\end{abstract}

Keywords: Open-Circuit Voltage; Chemical Modification; Indium-Tin Oxide

\section{Introduction}

Organic photovoltaic (PV) cells have been attracted much attention in recent decades due to their potentials as fabrication, low-cost production, and technological advantages of semiconductor materials [1-5]. Since the first report of donor-acceptor heterojunction with a power conversion efficiency $\left(\eta_{\mathrm{p}}\right)$ of about $1 \%$ by Tang [6], new materials and device structures have been developed in PV cells [7-15]. After the first report of organic PV cells, the performances of this type of cells have been significantly improved to reach $\eta_{\mathrm{p}}$ in a range of $3 \%-8 \%[8,9,16,17]$. However, such efficiency is not sufficient for practical use, and further improvement is required.

To obtain large open-circuit voltage $\left(V_{\mathrm{oc}}\right)$, Taima et al. introduced a $p$-type semiconductor 5, 6, 11, 12-tetraphenylnaphthacene (rubrene), which has the HOMO level of $5.4 \mathrm{eV}$. They obtained the $V_{\mathrm{oc}}$ of $0.91 \mathrm{~V}$ [18]. Forrest et al. introduced an excellent $p$-type semiconductor boron subphthalocyanine chloride (SubPc) with a low HOMO level of $5.6 \mathrm{eV}$ [19].

Indium-tin-oxide (ITO) is the most widely used as a transparent anode in organic PV cells due to its high conductivity, work function, and transparency in the visible spectral range [6]. Thus, various surface treatments of ITO have been attempted to change the work function of ITO in order to improve the properties of ITO substrates and control the charge injection barrier height reviewed in previous reports [20,21]. Although a number of groups have shown that chemical modification of ITO can be used to optimize the performance of organic lightemitting diodes (OLEDs) [20,21], there have been limited attempts to use chemical modification or chemically selfassembled monolayers (SAMs) in organic PV cells [22,23].

To investigate the possibility of increase in $V_{\text {oc }}$ by controlling the work functions of the electrodes, we report 
here the use of chemically modified ITO with different terminal groups ( $\mathrm{H}$ - and $\mathrm{Cl}-$ ) of $p$-benzenesulfonyl chlorides and $p$-chlorophenyldichlorophospate (-P) forming effective monolayers. We examine the correlation between the change in the work function of ITO and the performance of the PV cells by the chemical modification and find that the large increase in $V_{\mathrm{oc}}$. In this work, we selected tris(8-hydroxyquinoline)aluminum $\left(\mathrm{Alq}_{3}\right)$ as an electron transport layer (ETL) to substitute for bathocuproine (BCP) in cells based on rubrene (Rub)/buckminsterfullerene $\left(\mathrm{C}_{60}\right)$ heterojunction. Moreover, to examine the further improvement of $V_{\text {oc }}$, we used a lithium carboxylate $\left(\mathrm{C}_{6} \mathrm{H}_{5} \mathrm{COOLi}\right)$ [24] as a cathode interface material with low-work function which was inserted between ETL and Al.

\section{Experimental}

ITO coated glass substrates with a sheet resistance of $c a$. $15 \Omega$ /square (Sanyo Vacuum Industries) were cleaned by sonication successively in two detergents (Extran MA 03, $\mathrm{pH}$ 6.8, MERCK and Kontaminon $\mathrm{O}, \mathrm{pH}$ 10, WAKO), rinsed with deionized water, and stored in isopropanol until being required. After cleaning with acetone and isopropanol (this cleaned ITO will be called hereafter "as-cleaned ITO" with notation of "ac") the ITO substrates were immersed for $5 \mathrm{~min}$ in dichloromethane solutions containing $1 \mathrm{mM}$ of (H- and Cl-) of $p$-benzenesulfonyl chlorides (Tokyo Chemical Industry) and $p$-chlorophenyldichlorophospate (Tokyo chemical industry). The modified ITO anodes were rinsed in pure dichloromethane and then vacuum dried for $\sim 1 \mathrm{~h}$.

$\mathrm{C}_{60}$ (purity $>99 \%$ ) (Tokyo Chemical Industry), the sublimed grade rubrene (Aldrich Co.) and $\mathrm{Alq}_{3}$ (Dojindo Labs), the reagent grade BCP (Kanto Chemical), and lithium benzoate (purity 99\%) (Aldrich Co.) were used without further purification. All the materials were deposited using vacuum evaporation under a pressure of 5 $7 \times 10^{-6}$ Torr at deposition rates of $1-1.5 \AA / \mathrm{s}$ for organic layers and $3-4 \AA / \mathrm{s}$ for $\mathrm{Al}$ cathode. The active area for all the cells was defined to be $5 \times 5 \mathrm{~mm}^{2}$ by using a shadow mask. The current density-voltage $(J-V)$ curves were measured under illumination of a simulated solar light with $100 \mathrm{~mW} \times \mathrm{cm}^{-2}$ (AM1.5G) by a solar simulator (Yamashita Denso, YSS-50). Electric data were taken using an Advantest R6145 DC voltage current source unit at room temperature in ambient atmosphere.

The absorption spectral data for all the thin film were taken using an UV-visible spectrophotometer (UV-265 $\mathrm{FW}$, Shimadzu) at room temperature in ambient atmosphere.

\section{Results and Discussions}

\subsection{Expected Energy Diagrams of PV Cells}

For a cell based on exciton dissociation by charge trans- fer at a donor-acceptor (D/A) interface, $\eta_{\mathrm{p}}$ is the product of the efficiencies [1] of four sequential steps 1) photon absorption leading to the generation of an exciton, 2) diffusion of the exciton to the D/A interface, 3) exciton dissociation (or charge separation) by charge-transfer (CT) at the D/A interface, and 4) collection of the free charge carriers at electrodes, i.e., charge transport to the anode (holes) and cathode (electrons), to supply a direct current.

Figure 1 shows the interfacial energy diagrams with shifts of vacuum level $(\Delta)$ at the interfaces due to dipole layer formation in four types of cells studied in the present work. In general, the work function of metal is changed by covering the metal surface with different materials [25]. First, we will discuss the shift at a $\mathrm{C}_{60} / \mathrm{Al}$ cathode interface. The photoemission study of the $\mathrm{C}_{60} / \mathrm{Al}$ interface revealed an abrupt vacuum-level shift of $\Delta=\sim$ $+0.9 \mathrm{eV}$ [26]. Namely, the work function of the $\mathrm{Al}$ electrode $(4.2 \mathrm{eV})$ was increased to $5.1 \mathrm{eV}$ by depositing a $\mathrm{C}_{60}$ film on an $\mathrm{Al}$ surface. This shift is schematically illustrated in Figures 1(a) and (b). The same energy level shift at the $\mathrm{C}_{60} / \mathrm{Al}$ interface was also reported previously [27]. Another group reported the shift of $+0.7 \mathrm{eV}$ for the $\mathrm{C}_{60} / \mathrm{Al}$ interface and that of $+0.9 \mathrm{eV}$ for the $\mathrm{C}_{60} / \mathrm{LiF}(0.5$ $\mathrm{nm}) / \mathrm{Al}$ interface [28]. In the latter case, the work function was increased from $3.6 \mathrm{eV}(\mathrm{LiF} / \mathrm{Al})$ to $4.5 \mathrm{eV}$ $\left(\mathrm{C}_{60} / \mathrm{LiF} / \mathrm{Al}\right)$. The increase in the work function for all cases described above is possibly interpreted by partial electron transfer from $\mathrm{Al}$ to $\mathrm{C}_{60}$ [26-28]. The HOMO and LUMO levels of $\mathrm{C}_{60}$ are reported to be $6.2 \mathrm{eV}$ and $3.7 \mathrm{eV}$, respectively [10]. The increase in the work function of the $\mathrm{Al}$ electrode, however, is not preferable to create the built-in potential $\left(V_{\mathrm{bi}}\right)$ to separate the charge effectively in the PV cells.

In order to decrease the work function of the $\mathrm{Al}$ electrode, we have to put another layer of less electron affinity than $\mathrm{C}_{60}$. As such materials, we examined $\mathrm{Alq}_{3}$ and BCP [10,16,20,29-31] LUMO levels of which are higher (i.e., less electron affinity) than that of $\mathrm{C}_{60}$. In fact, the organic side for these interfaces is charged positively, making this side more comfortable (low energy) for an electron, and making the sign of $\Delta$ negative. Taking into account the $\Delta$ at $\mathrm{Alq}_{3} / \mathrm{Al}$ interface of $\sim-1.0 \mathrm{eV}$ [25], the resulting work function of $\mathrm{Alq}_{3} / \mathrm{Al}$ is decreased from the value of metallic $\mathrm{Al}(4.2 \mathrm{eV})$ [16] down to $3.2 \mathrm{eV}$ as shown in Figures 1(c)-(d). The work function of the $\mathrm{LiF} / \mathrm{Al}$ substrate was also gradually decreased upon $\mathrm{Alq}_{3}$ deposition, from $3.6 \mathrm{eV}$ to $3.1 \mathrm{eV}$ for $\mathrm{Alq}_{3}$ film deposition [28,32]. Toyoshima et al. reported the electronic structure at the interface between $\mathrm{BCP}$ and $\mathrm{Al}$ by UV photoemission spectroscopy [33]. Their results for BCP /Al interface were similar to the shift in the work function as observed at $\mathrm{Alq}_{3} / \mathrm{Al}$ interface $[25,32]$. In this way, we constructed the energy diagrams of the $\mathrm{Al}$ cathode side as shown in Figure 1. 
(a)
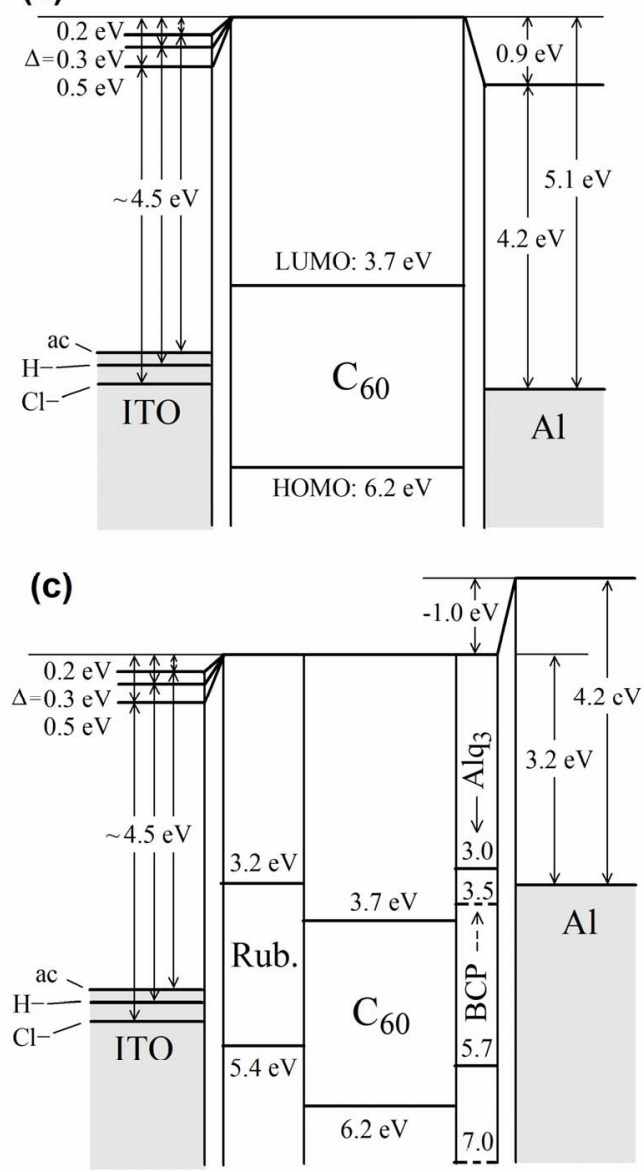

(b)

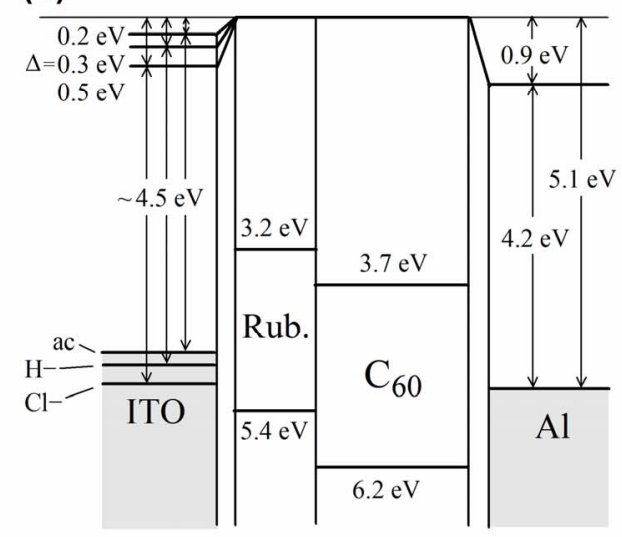

(d)

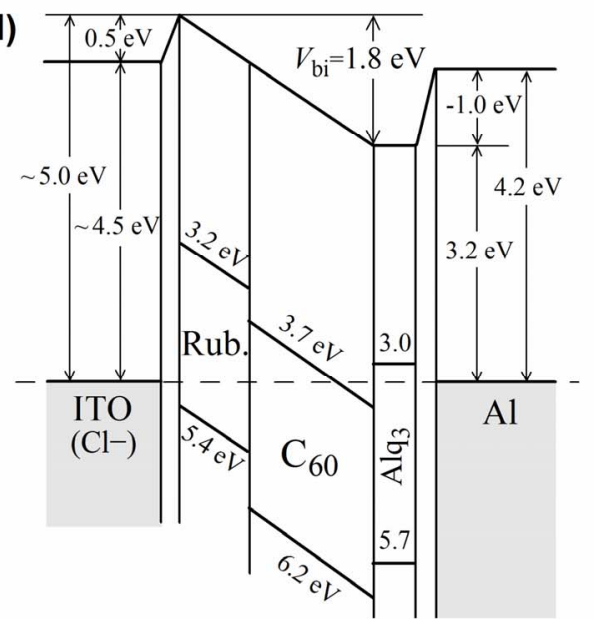

Figure 1. Interfacial energy diagrams with the shifts of vacuum level $(\Delta)$ at the interfaces due to dipole layer formation in the $P V$ cells. These lead to buildup of built-in potential $\left(V_{b i}\right)$ as shown in (d).

Next, we discuss the work function control of the anode side. The molecular approach allows for fine-tuning the work function using organic molecules on ITO depending upon magnitude and direction of the dipole moment [34]. The effective work functions formed by chemical modification of ITO shown in Figure 1 were estimated from the contact potential difference (CPD) values $[34,35]$.

An interface dipole with its negative end pointing toward the organic layer and its positive end toward the electrode surface increases the ITO work function (i.e., the Fermi energy is down) and HOMO energy level in the organic layer is relatively up by adding an electrostatic energy [8] as shown in Figure 1. When the cells studied have the same cathode material, the changes in $V_{\mathrm{bi}}$ obtained for cells with variously modified ITO electrodes are equal to the changes in the ITO work function. This is illustrated on the left side of Figure 1, where we consider that the ITO work function is in the range 4.5 $5.0 \mathrm{eV}$. The HOMO and LUMO values for rubrene are reported to be $5.4 \mathrm{eV}$ and $3.2 \mathrm{eV}$, respectively [18]. The work function control at the anode as well the cathode leads to buildup of a large $V_{\text {bi }}$ as shown in Figure 1(d). The dipole layers at interfaces may have a deep impact on the $V_{\mathrm{bi}}$ and consequently on the $V_{\mathrm{oc}}$ of organic PV cells.

\subsection{Characteristics of PV Cells}

Figure 2 shows the effect of ITO work function on the current density-voltage $\left(J-V_{\text {bias }}\right)$ characteristics under 100 $\mathrm{mW} \times \mathrm{cm}^{-2}$ illumination and in dark of four kinds of the PV cells with various surface treatments of ITO. Figure 2(a) shows the room temperature $J-V_{\text {bias }}$ characteristics of ITO(variously treated) $/ \mathrm{C}_{60}(60 \mathrm{~nm}) / \mathrm{Al}$ single-layer cells with a focus on the dark conduction properties. A linear fitting of the log-log plot (not shown) for these cells shows that the current for forward bias (electrons injection from the top contact) increases much slower (a slope is $\sim 1$ ) than the space-charge limited conduction (SCLC) [36]. Conducting charge transfer complex formed on $\mathrm{C}_{60} /$ metal interface was studied in previous report [37]. The gap state, pinning the Fermi level close to the LUMO of $\mathrm{C}_{60}$ molecules, is originating from the $\mathrm{C}_{60}$-metal complex formation at the interface [37]. The unoccupied 

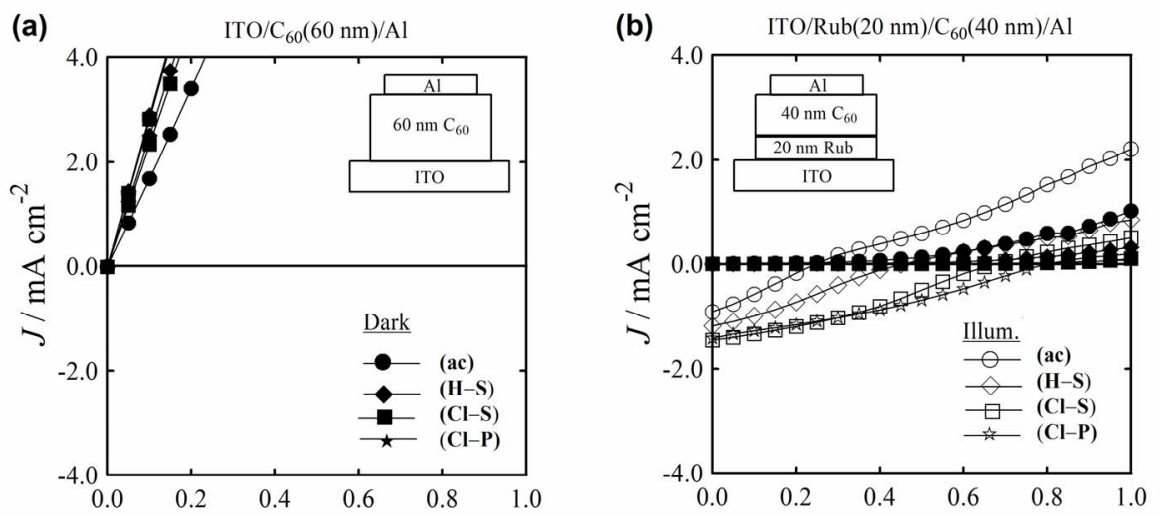

(c) $\mathrm{ITO} / \mathrm{Rub}(20 \mathrm{~nm}) / \mathrm{C}_{60}(40 \mathrm{~nm}) / \mathrm{Alq}_{3}(10 \mathrm{~nm}) / \mathrm{Al}$
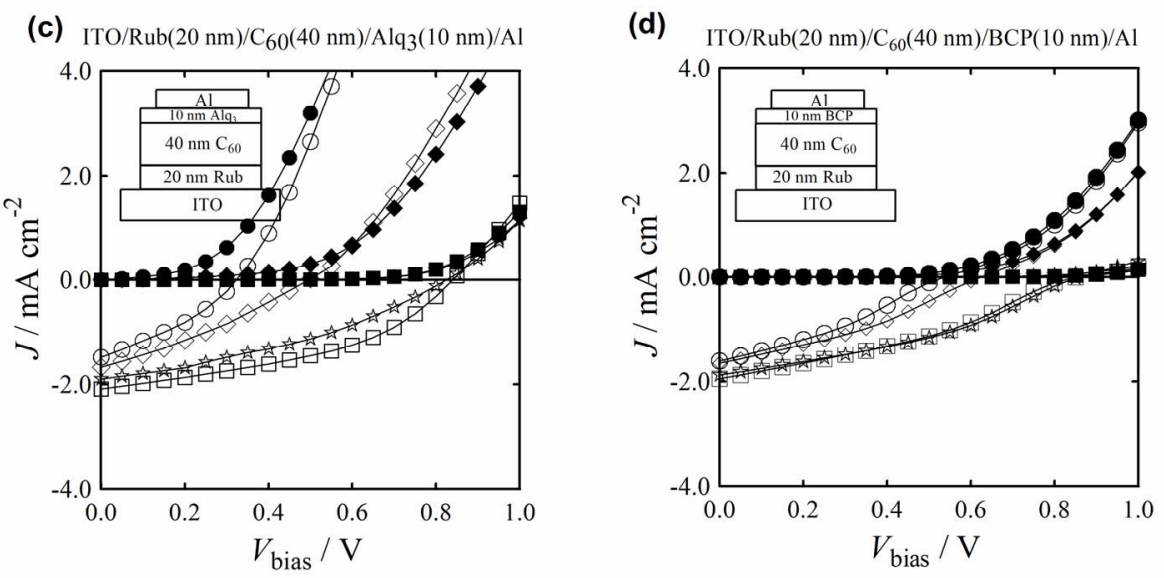

Figure 2. The effect of ITO work function on the $J-V_{\text {bias }}$ characteristics under $100 \mathrm{~mW} \times \mathrm{cm}^{-2}$ illumination and in dark of the cells with various surface treatments of ITO: (a) single-layer C60, (b) two-layer Rub/C60, and three-layers (c) with Alq ${ }_{3}$, and (d) with BCP.

states of the $\mathrm{C}_{60}$-metal complex appeared between the Fermi level and LUMO of $\mathrm{C}_{60}$ molecules lower the injection barrier which directly explains the improved device characteristics [37]. These states lead to the formation of Ohmic contact at the $\mathrm{C}_{60} / \mathrm{Al}$. A thin $\mathrm{LiF}$ interlayer inserted between $\mathrm{C}_{60}$ film and $\mathrm{Al}$ cathode gave an effective passivation for the contacts by preventing Al oxidation [38]. It appears that a thin interlayer can help to perverse the SCLC in $\mathrm{C}_{60}$ film and cells under exposure to air, by considerably suppressing the oxygen diffusion into the $\mathrm{C}_{60}$ film and reaction at the $\mathrm{C}_{60} / \mathrm{Al}$ interface [38].

In Figures 2(b) and (c), the $V_{\text {oc }}$ was most effectively increased when Cl-terminated benzenesulfonyl chloride was used. With ITO modified with H-terminated benzenesulfonyl chloride without any appreciable dipole moment in the para-position, the characteristics of PV cells were much better than those on as-cleaned ITO. From the results, the PV characteristics, in particular the $V_{\mathrm{oc}}$, which were well correlated with the work function change, were dramatically improved by the chemical modification of ITO.

The changes in $V_{\text {oc }}$ resulting from changes in the self-assembling dipole molecules used to coat the ITO surfaces follow the work function changes for the resulting ITO electrodes. Higher work function anodes result in larger values of the $V_{\mathrm{oc}}$ in the cells studied in the present work. In Figure 2(c), it can be seen, for example, that the $V_{\mathrm{oc}}$ can be increased from $0.35 \mathrm{~V}$ (as-cleaned ITO anode) to $0.48 \mathrm{~V}$ by grafting benzenesulfonyl chloride onto the ITO electrode. By grafting a monolayer of $p$-chlorobenzenesulfonyl chloride molecules results in a further increase in the $V_{\text {oc }}$ to $0.84 \mathrm{~V}$.

A dramatic effect of $\mathrm{Alq}_{3}(10 \mathrm{~nm})$ or BCP $(10 \mathrm{~nm})$ as a buffer layer deposited between $\mathrm{C}_{60}$ and $\mathrm{Al}$ on the measured $J$ - $V_{\text {bias }}$ characteristics is clearly observed in Figures 2(b)-(d). The PV cells with $\mathrm{Alq}_{3}$ or BCP exhibited the best $J-V_{\text {bias }}$ characteristics and gave the typical diode characteristics. BCP is the material selected as an exciton blocking layer [16]. $\mathrm{Alq}_{3}$ is a good ETL material widely used in OLEDs [34]. It can be seen in Figures 2(c) and (d) that the cells exhibited similar PV characteristics, indicating that band gaps and LUMO levels of the materials of $\mathrm{Alq}_{3}$ and $\mathrm{BCP}$ have minor effects on the PV performances. As shown in Figure 1(c), while bandgaps and LUMO levels of $\mathrm{Alq}_{3}$ and BCP are different, the performance of the cells is not significantly changed by dif- 
ferent ETL materials (Table 1). This indicates that electron transport in these cells should not be via LUMO levels of these ETL materials. The results suggest that the most important role of $\mathrm{Alq}_{3}$ or $\mathrm{BCP}$ is to establish an Ohmic contact between $\mathrm{Al}$ and $\mathrm{C}_{60}$ i.e., a protective film on $\mathrm{C}_{60}$ [39].

While alkali metal-doped organic materials such as $\mathrm{Alq}_{3}$ have been used as an ETL in OLEDs [40,41] this approach has been not been explored in organic PV cells. Recently, we observed the alkali metal formation by thermal decomposition during vapor deposition of alkali metal carboxylates without post-deposition of $\mathrm{Al}$ cathode [42].

The improvement was attributed to the reaction of hot $\mathrm{Al}$ atoms with $\mathrm{C}_{6} \mathrm{H}_{5} \mathrm{COOLi}$ to form metallic Li during $\mathrm{Al}$ vapor deposition [41]. The resulting metallic Li was believed to dope the $\mathrm{Alq}_{3}$ layer [40] and to alloy with the $\mathrm{Al}$ cathode [24]. To examine the influence of induced $V_{\mathrm{bi}}$ on the performance of the cells, a $2 \mathrm{~nm} \mathrm{C}_{6} \mathrm{H}_{5} \mathrm{COOLi}$ as a cathode interface material deposited between $\mathrm{C}_{60}$ or $\mathrm{C}_{60} / \mathrm{Alq}_{3}$ (or $\mathrm{C}_{60} / \mathrm{BCP}$ ) and $\mathrm{Al}$ cathode was used. The $J-V_{\text {bias }}$ characteristics of the ITO (modified with $\mathrm{Cl}-$ )/ $\operatorname{Rub}(20 \mathrm{~nm}) / \mathrm{C}_{60}(40 \mathrm{~nm}) / \mathrm{Al}$ with variously configured cathodes under $100 \mathrm{~mW} \times \mathrm{cm}^{-2}$ illumination and in dark are shown in Figure 3. The PV performances of the cells are summarized in Table 1. Among all the cells studied, we found that the large increase in $V_{\text {oc }}$ for the ITO (modified with Cl-)/Rub $(20 \mathrm{~nm}) / \mathrm{C}_{60}(40 \mathrm{~nm}) / \mathrm{Alq}_{3}(10$ $\mathrm{nm}) / \mathrm{Li} / \mathrm{Al}$ cell. We obtained the $V_{\text {oc }}$ of $0.92 \pm 0.1 \mathrm{~V}$.

In Figure 3 and Table 1, the $V_{\text {oc }}$ of cell with the $\mathrm{Alq}_{3} / \mathrm{Li} / \mathrm{Al}$ is the highest, and followed by the $\mathrm{BCP} / \mathrm{Li} / \mathrm{Al}$, $\mathrm{Alq}_{3} / \mathrm{Al}$ or $\mathrm{BCP} / \mathrm{Al}, \mathrm{Al}$, and $\mathrm{C}_{6} \mathrm{H}_{5} \mathrm{COOLi} / \mathrm{Al}$ cells. The results suggest the importance of lower work function of $\mathrm{Li}(2.9 \mathrm{eV})$ for the larger $V_{\text {oc }}[41]$. The $V_{\mathrm{bi}}$ is increased to larger value, giving an interfacial dipole, which may be attributed to both the alloy formation at the $\mathrm{Al}$ cathode [24,41] and doping of $\mathrm{Alq}_{3}$ with $\mathrm{Li}$ [40-43]. The ITO (modified with Cl-)/Rub $(20 \mathrm{~nm}) / \mathrm{C}_{60}(40 \mathrm{~nm}) / \mathrm{Li} / \mathrm{Al}$ cell exhibited the lowest $V_{\text {oc }}$. It may be considered, however, from our recent study of quenching by the presence of excess and colored species [44] that the doping of $\mathrm{C}_{60}$

Table 1. The performances of organic $P V$ cells with a structure of ITO(Cl- $) / \mathrm{Rub} / \mathrm{C}_{60} / \mathrm{Al}$ with different configured cathodes under $100 \mathrm{~mW} \times \mathrm{cm}^{-2}$ illumination.

\begin{tabular}{ccccc}
\hline Cathode structures & $\begin{array}{c}J_{\mathrm{sc}} \\
\left(\mathrm{mA} \times \mathrm{cm}^{-2}\right)\end{array}$ & $\begin{array}{c}V_{\text {oc }} \\
(\mathrm{V})\end{array}$ & FF & $\begin{array}{c}\eta_{\mathrm{p}} \\
(\%)\end{array}$ \\
\hline $\mathrm{Al}$ & 1.46 & 0.68 & 0.37 & 0.36 \\
$\mathrm{C}_{6} \mathrm{H}_{5} \mathrm{COOLi} / \mathrm{Al}$ & 0.80 & 0.21 & 0.37 & 0.06 \\
$\mathrm{BCP} / \mathrm{Al}$ & 1.95 & 0.85 & 0.35 & 0.58 \\
$\mathrm{BCP} / \mathrm{C}_{6} \mathrm{H}_{5} \mathrm{COOLi} / \mathrm{Al}$ & 2.06 & 0.82 & 0.43 & 0.73 \\
$\mathrm{Alq}_{3} / \mathrm{Al}$ & 2.09 & 0.84 & 0.45 & 0.79 \\
$\mathrm{Alq}_{3} / \mathrm{C}_{6} \mathrm{H}_{5} \mathrm{COOLi} / \mathrm{Al}$ & 2.10 & 0.93 & 0.40 & 0.78 \\
\hline
\end{tabular}

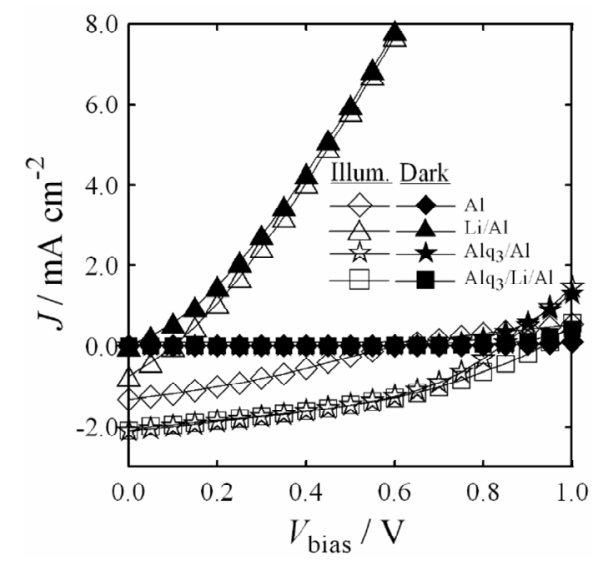

Figure 3. $J-V_{\text {bias }}$ characteristics of the ITO(Cl- $) / \mathrm{Rub} / \mathrm{C}_{60} / \mathrm{Al}$ with variously configured cathodes under $100 \mathrm{~mW} \times \mathrm{cm}^{-2}$ illumination and in dark.

with $\mathrm{Li}$ increases exciton quenching and so that more excitons cannot contribute to the generation of electricity. Srdanov et al. reported results of an in-situ optical absorption study on alkali metal-doped thin films of $\mathrm{C}_{60}$ [45].

Gregg and Hanna proposed that the $V_{\text {oc }}$ is controlled by a chemical potential energy gradient of the organic PV cells [46]. The chemical potential gradient is equivalent to the carrier concentration gradient and would depend on the carrier mobility. Based on this idea, $V_{\text {oc }}$ is dependent on the hole mobility [47]. The $V_{\mathrm{bi}}$ still plays a role in most organic PV cells. Both the chemical potential and the electrical potential must be taken into account [46].

In bilayer cells, the $V_{\mathrm{oc}}$ scales linearly with the work function difference, however, with an additional contribution depending on the light intensity. This contribution is due to the accumulation of charge carriers at the D/A interface, giving rise to a diffusion current which must be compensated by a drift current at open circuit [48]. Under illumination, charges are separated across the D/A interface. Due to the concentration gradient, carriers will diffuse away from the interface, leading to a net diffusion current. The effect of diffusion on $V_{\text {oc }}$ in single-layer PV cells has been studied by Malliaras et al. [49]. The accumulated charges at the interface will create a bandbending, which leads to a reduction of the electric field in the bulk of the cell.

In addition to attempts to optimize the components and composition of the active layer, modification of the electrodes has also lead to an improvement in device performance [50]. It is evident that the work function of the negatively charged electrode is relevant for the $V_{\text {oc }}$ of the cells. In the classical metal-insulator-metal (MIM) concept, the $V_{\text {oc }}$ is in first order approximation governed by the work function difference of the anode and the cathode, respectively. It should be noted that this only holds for the case where the Fermi levels of the contacts are 
within the bandgap of the insulator and are sufficiently far way from the HOMO and the LUMO levels, respectively [51]. In the case of ohmic contacts, meaning that the negative and positive electrodes match the LUMO level of the acceptor and the HOMO level of the donor, respectively, the situation is different; charge transfer of electrons or holes from the metal into the semiconductor occurs in order to align the Fermi level at the negative and positive electrode, respectively [51]. As a result, the electrode work functions become pinned close to the LUMO/HOMO level of semiconductor [50]. Because of this pinning, the $V_{\text {oc }}$ will be governed by the energetics of the LUMO of the acceptor and the HOMO of the donor. Indeed, in bilayer cells, a linear correlation of the $V_{\mathrm{oc}}$ with the reduction potential of the acceptor has been reported [52].

For cells with non-ohmic contacts, the observed $V_{\text {oc }}$ is in agreement the expected values [50]. In this case, the $V_{\mathrm{oc}}$ is determined by the work function differences of the electrodes. However, for the Ohmic contact the measured value is lower that the predicted value, possibly due to the energetic disorder of the charge transport levels [50]. Furthermore, generation of free charges is enhanced by an electric field in the appropriate direction. Possible mechanism by which balance between electron and hole escape currents can be maintained in the steady state is by the build-up of a net charge density within the cell. This acts to reduce the electric field (and hence suppress the generation of free charges) at one electrode and increase it at the other [53]. Snaith et al. found that a charge injection barrier from electrodes into the polymer film helps to retain a high $V_{\mathrm{oc}}$ in the blend cell [53].

\section{Conclusion}

We have studied the use of chemically modified ITO with 4-chlorophenyldichlorophospate and different terminal groups ( $\mathrm{H}-$ and $\mathrm{Cl}-$ ) of $p$-benzenesulfonyl chlorides forming effective monolayers to control work function of ITO for enhancing the $V_{\text {oc }}$ in organic PV cells. We have examined the correlation between the change in the work functions of electrodes and the performance of the PV cells before and after the surface modification and found that there is an large increase in $V_{\text {oc }}$ for the ITO (modified with $\mathrm{Cl}-) / \mathrm{Rub}(20 \mathrm{~nm}) / \mathrm{C}_{60}(40 \mathrm{~nm}) / \mathrm{Alq}_{3}(10 \mathrm{~nm}) /$ $\mathrm{C}_{6} \mathrm{H}_{5} \mathrm{COOLi}(2 \mathrm{~nm}) / \mathrm{Al}$. We obtained the $V_{\text {oc }}$ of $0.92 \pm$ $0.1 \mathrm{~V}$. Controlling the work functions of electrodes by surface modification at the interfaces is a key parameter, which is useful for interpreting the origin of the opencircuit voltage and leads to improvements in the $J$-V bias characteristics of the cells.

\section{REFERENCES}

[1] C. Lee, P. Linneman, P. Peumans, A. Yakimow and S. R.
Forrest, "Small Molecular Weight Organic Thin-Film Photodetectors and Solar Cells," Journal of Applied Physics, Vol. 93, No. 7, 2003, pp. 3693-3723. http://dx.doi.org/10.1063/1.1534621

[2] S. R. Forrest, "The Path to Ubiquitous and Low-Cost Organic Electronic Applications on Plastic," Nature, Vol. 428, No. 6994, 2004, pp. 911-918. http://dx.doi.org/10.1038/nature02498

[3] T. Kietzke, "Recent Advances in Organic Solar Cells," Advances in OptoElectronics, Vol. 2007, No. 40285, 2007, pp. 1-15. http://dx.doi.org/10.1155/2007/40285

[4] J. Xue, "Perspectives on Organic Photovoltaics," Polymer Reviews, Vol. 50, No. 4, 2010, pp. 411-419. http://dx.doi.org/10.1080/15583724.2010.515766

[5] F. C. Krebs, "Polymeric Solar Cells: Materials, Design, Manufacture,” DEStech Publications, Inc., Lancaster, 2010.

[6] C. W. Tang, "Two-Layer Organic Photovoltaic Cell," Applied Physics Letters, Vol. 48, No. 2, 1986, pp. 183-185. http://dx.doi.org/10.1063/1.96937

[7] Z. R. Dai, Z. W. Pan and Z. L. Wang, "Novel Nanostructures of Functional Oxides Synthesized by Thermal Evaporation," Advanced Functional Materials, Vol. 13, No. 1, 2003, pp. 9-24.

http://dx.doi.org/10.1002/adfm.200390013

[8] J. Xue, S. Uchida, B. P. Rand and S. R. Forrest, " $4.2 \%$ Efficient Organic Photovoltaic Cells With Low Series Resistances," Applied Physics Letters, Vol. 84, No. 16, 2004, pp. 3013-3016. http://dx.doi.org/10.1063/1.1713036

[9] J. Xue, S. Uchida, B. P. Rand and S. R. Forrest, "Asymmetric Tandem Organic Photovoltaic Cells with Hybrid Planar-Mixed Molecular Heterojunctions," Applied Physics Letters, Vol. 85, No. 23, 2004, pp. 5757-5759. http://dx.doi.org/10.1063/1.1829776

[10] C. F. Lin, M. Zhang, S. W. Liu, T. L. Chiu and J. H. Lee, "High Photoelectric Conversion Efficiency of Metal Phthalocyanine/Fullerene Heterojunction Photovoltaic Device," International Journal of Molecular Sciences, Vol. 12, No. 1, 2011, pp. 476-505. http://dx.doi.org/10.3390/ijms12010476

[11] G. Dennler, M. C. Scharber and C. J. Brabec, "PolymerFullerene Bulk-Heterojunction Solar Cells," Advanced Materials, Vol. 21, No. 13, 2009, 1323-1338. http://dx.doi.org/10.1002/adma.200801283

[12] H. Y. Chen, et al., "Polymer Solar Cells with Enhanced Open-Circuit Voltage and Efficiency," Nature Photonics, Vol. 3, No. 11, 2009, pp. 649-653. http://dx.doi.org/10.1038/nphoton.2009.192

[13] G. E. Morse and T. P. Bender, "Boron Subphthalocyanines as Organic Electronic Materials," ACS Applied Materials \& Interfaces, Vol. 4, No. 10, 2012, pp. 5055-5068. http://dx.doi.org/10.1021/am3015197

[14] G. Li, R. Zhu and Y. Yang, "Polymer Solar Cells," Nature Photonics, Vol. 6, No. 3, 2012, pp. 153-161. http://dx.doi.org/10.1038/nphoton.2012.11

[15] J. Yang, L. Qian, R. Zhou, Y. Zheng, A. Tang and P. H. Holloway, "Hybrid Polymer: Colloidal Nanoparticle Photovoltaic Cells Incorporating a Solution-Processed, Multi- 
Functioned ZnO Nanoscrystal Layer," Journal of Applied Physics, Vol. 111, No. 4, 2012, pp. 044323-044330. http://dx.doi.org/10.1063/1.3689154

[16] P. Peumans and S. R. Forrest "Very-High-Efficiency Double-Heterostructure Copper Phthalocyanine/ $\mathrm{C}_{60}$ Photovoltaic Cells," Applied Physics Letters, Vol. 79, No. 1, 2001, pp. 126-128. http://dx.doi.org/10.1063/1.1384001

[17] M. A. Green, K. Emery, Y. Hishikawa and W. Warta, "Solar Cell Efficiency Tables (Version 37)," Progress in Photovoltaics, Vol. 19, No. 1, 2011, pp. 84-92. http://dx.doi.org/10.1002/pip.1088

[18] T. Taima, J. Sakai, T. Yamanari and K. Saito, "Realization of Large Open-Circuit Photovoltage in Organic ThinFilm Solar Cells by Controlling Measurement Environment," Japanese Journal of Applied Physics, Vol. 45, No. 37, 2006, pp. L995-L997. http://dx.doi.org/10.1143/JJAP.45.L995

[19] K. L. Mutolo, E. I. Mayo, B. P. Rand, S. R. Forrest and M. E. Thompson, "Enhanced Open-Circuit Voltage in Subphthlocyanine $/ \mathrm{C}_{60}$ Organic Photovoltaic Cells," Journal of the American Chemical Society, Vol. 128, No. 25, 2006, pp. 8108-8109. http://dx.doi.org/10.1021/ja061655o

[20] M. Fujihira and C. Ganzorig, "Conjugated Polymer and Molecular Interfaces," In: A. Kahn, J. J. Pireaux, W. R. Salaneck and K. Seki, Eds., Marcel Dekker, New York, 2002, pp. 817-858.

[21] C. Ganzorig and M. Fujihira, "Chemically Modified Oxide Electrodes," In: A. J. Bard and M. Stratmann, Eds., Modified Electrodes, WILEY-VCH Verlag GmbH, Weinheim, 2007, pp. 261-334.

[22] N. R. Armstrong, et al., "Interface Modification of ITO Thin Films: Organic Photovoltaic Cells," Thin Solid Films, Vol. 445, No. 2, 2003, pp. 342-352. http://dx.doi.org/10.1016/j.tsf.2003.08.067

[23] S. Khodabakhsh, B. M. Sanderson, J. Nelson and T. S. Jones, "Using Self-Assembling Dipole Molecules to Improve Charge Collection in Molecular Solar Cells," Advanced Functional Materials, Vol. 16, No. 1, 2006, pp. 95-100. http://dx.doi.org/10.1002/adfm.200500207

[24] C. Ganzorig and M. Fujihira, "A Lithium Carboxylate Ultrathin Film on an Aluminum Cathode for Enhanced Electron Injection in Organic Electroluminescent Devices," Japanese Journal of Applied Physics, Vol. 38, No. 11B, 1999, pp. L1348-L1350. http://dx.doi.org/10.1143/JJAP.38.L1348

[25] H. Ishii, K. Sugiyama, E. Ito and K. Seki, "Energy Level Alignment and Interfacial Electronic Structures at Organic/Metal and Organic/Organic Interfaces," Advanced Materials, Vol. 11, No. 8, 1999, pp. 605-625.

http://dx.doi.org/10.1002/(SICI)1521-4095(199906)11:8< 605::AID-ADMA605>3.0.CO;2-Q

[26] A. J. Maxwell, P. A. Bronwiler, D. Arvanitis, J. Hasselstrom, M. K. J. Johansson and N. Martensson, "Electronic and Geometric Structure of $\mathrm{C}_{60}$ on $\mathrm{Al}(111)$ and $\mathrm{Al}(110)$," Physical Review B, Vol. 57, No. 12, 1998, pp. 7312-7326. http://dx.doi.org/10.1103/PhysRevB.57.7312

[27] J. Y. Lee, "Efficient Hole Injection in Organic Light Emitting Diodes Using $\mathrm{C}_{60}$ as a Buffer Layer for Al Re- flective Anodes," Applied Physics Letters, Vol. 88, No. 7, 2006, pp. 073512-073514.

http://dx.doi.org/10.1063/1.2174838

[28] S. K. M. Jonsson, W. R. Salaneck and M. Fahlman, "Photoemission of $\mathrm{Alq}_{3}$ and $\mathrm{C}_{60}$ film on $\mathrm{Al}$ and $\mathrm{LiF}$ Substrates," Journal of Applied Physics, Vol. 98, No.1, 2005, pp. 014901-014907. http://dx.doi.org/10.1063/1.1929884

[29] R. Mitsumoto, et al., "Electronic Structures and Chemical Bonding of Fluorinated Fullerenes Studied by NEXAFS, UPS and Vacuum-Absorption Spectroscopies," Journal of Physical Chemistry A, Vol. 102, No. 3, 1998, pp. 552560. http://dx.doi.org/10.1021/jp972863t

[30] M. Hayashi, H. Ishii, Y. Ouchi and K. Seki, "Examination of Band Bending at Buckminsterfullerene $\left(\mathrm{C}_{60}\right)$ Metal Interfaces by the Kelvin Probe Method," Journal of Applied Physics, Vol. 92, No. 7, 2002, pp. 3784-3793. http://dx.doi.org/10.1063/1.1504495

[31] Y. Tanaka, K. Kanai, Y. Ouchi and K. Seki, "Oxygen Effect in the Interfacial Electronic Structure of $\mathrm{C}_{60}$ Film Studied by Photoelectron Spectroscopy," Chemical Physics Letters, Vol. 441, No. 1-3, 2007, pp. 63-70. http://dx.doi.org/10.1016/i.cplett.2007.04.080

[32] T. Yokoyama, D. Yoshimura, E. Ito, H. Ishii, Y. Ouchi and K. Seki, "Energy Level Alignment at $\mathrm{Alq}_{3} / \mathrm{LiF} / \mathrm{Al}$ Interfaces Studied by Electron Spectroscopies: Island Growth of $\mathrm{LiF}$ and Size-Dependence of the Electronic Structures," Japanese Journal of Applied Physics, Vol. 42, No. 6A, 2003, pp. $3666-3675$. http://dx.doi.org/10.1143/JJAP.42.3666

[33] S. Toyoshima, K. Kuwabara, T. Sakurai, T. Taima, K. Saito, H. Kato and K. Akimoto, "Electronic Structure of Bathocuproine on Metal Studied by Ultraviolet Photoemission Spectroscopy," Japanese Journal of Applied Physics, Vol. 46, No. 4B, 2007, pp. 2692-2695. http://dx.doi.org/10.1143/JJAP.46.2692

[34] C. Ganzorig, K. J. Kwak, K. Yagi and M. Fujihira, "Fine Tuning Work Function of Indium Tin Oxide by Surface Molecular Design: Enhanced Hole Injection in Organic Electroluminescent Devices," Applied Physics Letters, Vol. 79, No. 2, 2001, pp. 272-274. http://dx.doi.org/10.1063/1.1384896

[35] K. Sarangerel, C. Ganzorig, M. Fujihira, M. Sakomura and K. Ueda, "Influence of the Work Function of Chemically Modified Indium-Tin-Oxide Electrodes on the OpenCircuit Voltage of Heterojunction Photovoltaic Cells," Chemistry Letters, Vol. 37, No. 7, 2007, pp. 778-779. http://dx.doi.org/10.1246/cl.2008.778

[36] C. Ganzorig, M. Sakomura, K. Ueda and M. Fujihira, "Current-Voltage Behavior in Hole-Only Single-Carrier Devices with Self-Assembling Dipole Molecules on Indium Tin Oxide Anodes," Applied Physics Letters, Vol. 89 , No. 26, 2006, pp. 263501-253603. http://dx.doi.org/10.1063/1.2420792

[37] S. W. Cho, et al., "Origin of Charge Transfer Complex Resulting in Ohmic Contact at the $\mathrm{C}_{60} / \mathrm{Cu}$ Interface," Synthetic Metals, Vol. 157, No. 2-3, 2007, pp. 160-164. http://dx.doi.org/10.1016/i.synthmet.2007.01.006

[38] C. J. Huang, D. Glozea, A. Turakn and Z. H. Lu, "Passivation Effect of $\mathrm{Al} / \mathrm{LiF}$ Electrode on $\mathrm{C}_{60}$ Diodes," Applied 
Physics Letters, Vol. 86, No. 3, 2005, pp. 033107-033109. http://dx.doi.org/10.1063/1.1854193

[39] M. Vogel, S. Doka, Ch. Breyer, M. Ch. Lux-Steiner and K. Fostiropoulos, "On the Function of a Bathocuproine Buffer Layer in Organic Photovoltaic Cells," Applied Physics Letters, Vol. 89, No. 16, 2006, pp. 163501163503. http://dx.doi.org/10.1063/1.2362624

[40] J. Kido and T. Matsumoto, "Bright Organic Electroluminescent Devices Having a Metal-Doped Electron-Injecting Layer," Applied Physics Letters, Vol. 73, No. 20, 1998, pp. 2866-2868. http://dx.doi.org/10.1063/1.122612

[41] C. Ganzorig, K. Suga and M. Fujihira, "Alkali Metal Acetates as Effective Electron Injection Layers for Organic Electroluminescent Devices," Materials Science and Engineering: B, Vol. 85, No. 2-3, 2001, pp. 140-143. http://dx.doi.org/10.1016/S0921-5107(01)00547-5

[42] C. Ganzorig and M. Fujihira, "Evidence for Alkali Metal Formation at a Cathode Interface of Organic Electroluminescent Devices by Thermal Decomposition of Alkali Metal Carboxylates during Their Vapor Deposition," Applied Physics Letters, Vol. 85, No. 20, 2004, pp. 47744776. http://dx.doi.org/10.1063/1.1819984

[43] N. Johansson, T. Osada, S. Stafstrom, W. R. Salaneck, V. Parente, D. A. dos Santos, X. Crispin and J. L. Bredas, "Electronic Structure of Tris(8-Hydroxyquinoline) Aluminum Thin Films in the Pristine and Reduced States," Journal of Chemical Physics, Vol. 111, No. 5, 1999, pp. 2157-2163. http://dx.doi.org/10.1063/1.479486

[44] C. Ganzorig and M. Fujihira, "A Possible Mechanism for Enhanced Electrofluorescence Emission through TripletTriplet Annihilation in Organic Electroluminescent Devices," Applied Physics Letters, Vol. 81, No. 17, 2002, pp. 3137-3139. http://dx.doi.org/10.1063/1.1515129

[45] V. I. Srdanov, C. H. Lee and N. S. Sariciftci, "Spectral and Photocarrier Dynamics in Thin Films of Pristine and Alkali-Doped $\mathrm{C}_{60}$," Thin Solid Films, Vol. 257, No. 2, 1995, pp. 233-243. http://dx.doi.org/10.1016/0040-6090(94)05707-9

[46] B. A. Gregg and M. C. Hanna, "Comparing Organic to
Inorganic Photovoltaic Cells: Theory, Experiment, and Simulation," Journal of Applied Physics, Vol. 93, No. 6, 2003, pp. 3605-3614. http://dx.doi.org/10.1063/1.1544413

[47] Y. Terao, H. Sasabe and C. Adachi, "Correlation of the Hole Mobility Exciton Diffusion Length, and Solar Cell Characteristics in Phthalocyanine/Fullerene Organic Solar Cells," Applied Physics Letters, Vol. 90, No. 10, 2007, 103515-103517. http://dx.doi.org/10.1063/1.2711525

[48] C. M. Ramsdale, et al., "The Origin of the Open-Circuit Voltage in Polyfluorene-Based Photovoltaic Devices," Journal of Applied Physics, Vol. 92, No. 8, 2002, pp. 4266-4270. http://dx.doi.org/10.1063/1.1506385

[49] G. G, Malliaras, J. R. Salem, P. J. Brock and J. C. Scott, "Photovoltaic Measurement of the Built-In Potential in Organic Light Emitting Diodes and Photodiodes," Journal of Applied Physics, Vol. 84, No. 3, 1998, pp. 15831587. http://dx.doi.org/10.1063/1.368227

[50] V. D. Mihailetchi, P. W. M. Blom, J. C. Hummelen and M. T. Rispens, "Cathode Dependence of The Open-Circuit Voltage of Polymer: Fullerene Bulk Heterojunction Solar Cells," Journal of Applied Physics, Vol. 94, No. 10, 2003, pp. 6849-6864. http://dx.doi.org/10.1063/1.1620683

[51] P. W. M. Blom, V. D. Mihailetchi, L. J. A. Koster and D. E. Markov, "Device Physics of Polymer: Fullerene Bilk Heterojunction Solar Cell," Advanced Materials, Vol. 19, No. 12, 2007, pp. 1551-1566. http://dx.doi.org/10.1002/adma.200601093

[52] C. J. Brabec, et al., "Origin of the Open Circuit Voltage of Plastic Solar Cells," Advanced Functional Materials, Vol. 11, No. 5, 2001, pp. 374-380. http://dx.doi.org/10.1002/1616-3028(200110)11:5<374:: AID-ADFM374>3.0.CO;2-W

[53] H. J. Snaith, N. C. Greenham and R. H. Friend, "The Origin of Collected Charge and Open-Circuit Voltage in Blended Polyfluorene Photovoltaic Devices," Advanced Materials, Vol. 16, No. 18, 2004, pp. 1640-1645. http://dx.doi.org/10.1002/adma.200305766 